\title{
The Role of Spirulina platensis (Arthrospira platensis) in Growth and Immunity of Nile Tilapia (Oreochromis niloticus) and Its Resistance to Bacterial Infection
}

\author{
Mai D. Ibrahem ${ }^{1}$, Mohamed F. Mohamed ${ }^{2} \&$ Marwa A. Ibrahim ${ }^{3}$ \\ ${ }^{1}$ Department of Fish Diseases and Management, Faculty of Veterinary Medicine, Cairo University, Giza, Egypt \\ ${ }^{2}$ Department of microbiology, The World Fish Organization, Regional Research for Africa \& West Asia, Abbasa, \\ Sharkia, Egypt \\ ${ }^{3}$ Department of Biochemistry, Faculty of Veterinary Medicine, Cairo University, Giza 12211, Egypt \\ Correspondence: Mai D. Ibrahem, Department of Fish Diseases and Management, Faculty of Veterinary Medicine, \\ Cairo University, Giza 12211, Egypt. Tel: 20-233-800-575. E-mail: ibrahemmai20@yahoo.com
}

Received: January 17, 2013 Accepted: March 26, 2013 Online Published: May 15, 2013

doi:10.5539/jas.v5n6p109 URL: http://dx.doi.org/10.5539/jas.v5n6p109

\begin{abstract}
The current study was designed to optimize the dietary levels of Spirulina platensis in Oreochromis niloticus; this was tested via graded levels. Six isonitrogenous and isocaloric rations containing graded levels of dried spirulina $0,5,7.5,10,15$ and $20 \mathrm{~g} / \mathrm{kg}$ diet were fed separately to six equal groups of $O$. niloticus fingerlings for 3 months. Growth performance, non-specific immune parameters, tissue reactions and resistance of tilapias post challenge infection with Pseudomonas fluorescens were estimated monthly. There were significant increase in growth performance parameters and survival rates in spirulina-supplemented groups at concentration level of 10 $\mathrm{g} / \mathrm{kg}$ for 2 months. Significant increases in hematocrit, nitroblue tetrazolium and lysozyme activity were observed in most of the supplemented groups. Bacterial challenge infections resulted in significantly lower mortality rate in all Spirulina groups with remarkable increase in protection of fish received $10 \mathrm{~g} / \mathrm{kg}$. In sum, it advisable to incorporate $10 \mathrm{~g} / \mathrm{kg}$ diet of spirulina for 2 months for maximum growth performance, immunity and disease resistance in $O$. niloticus.
\end{abstract}

Keywords: Spirulina platensis, growth performance, hematocrit, nitroblue tetrazolium, lysozyme activity, challenge infection

\section{Introduction}

The increase in aquaculture production could be accomplished either by increasing the cultured area or intensification of production. Under such extreme conditions; several growth and immune suppressors can take place (Yousefian \& Amiri, 2009), in addition, aquatic organisms are in constant contact with a plethora of bacteria, many of which are pathogenic (Kaizu et al., 2011).

Several sectors of the aquaculture industry would benefit if cultured organisms were conferred with enhanced feed efficiency, growth performance, and disease resistance without environmental conflicts (Gatlin et al., 2006). Functional feed additives strategy has recently gained considerable attention. From nutritional point of view; it does not only provide the essential nutrients required for normal physiological functioning, but also serve as a medium by which fish receive other components that may positively affect their health (Ibrahem et al., 2010) . Researches on diets optimization to enhance fish health and production are still in infancy.

There are increasing recognition for the importance of aquatic macrophytes as feed in aquaculture. Tilapias are omnivorous that can utilize cyanobacterial blue-green algae (Chow \& Woo, 1990). Spirulina platensis (SP), a filamentous cyanobacterium, possesses diverse biological and nutritional significance. It has the potentiality to produce large numbers of antimicrobial substances; therefore, it is considered a suitable candidate for exploitation as bio-control agent against pathogenic micro-organisms (Ozdemir et al., 2004). In aquaculture, different forms of SP were tested in various fish and shellfish species (Ungsethaphand et al., 2010). 
Optimization of dried form of whole $S$. platensis concentration in fish diets is still questionable, regarding its optimum concentration needed to reach its desired effects on growth performance, feed utilization, immune responses, and resistance of tilapias to infections.

SP is well known for its anti-oxidant and anti-cancerous properties. A hot water extract of SP has been orally administered to patients and proved as an anti-cancer agent. SP hinders the growth of oral cancer in Syrian hamster cheek (Grawish, 2008). Such an inhibitory effect may be attributed to the repair of carcinogen- damaged DNA, meanwhile, SP has been suggested as an efficient radical scavenger (Romay et al., 1998). Several studies reported the unique role of SP polysaccharides in enhancing the cell nucleus enzyme activity and the process of DNA repair (Kaji et al., 2002).

Therefore, the overall goals of the present study are to investigate the optimum dietary concentration and duration of dried S. platensis needed to exert its potential effects on growth performance, immunomodulator, chemoprotective agent, in addition to the resistance of $O$. niloticus supplemented groups to Pseudomonas fluorescens infections.

\section{Materials and Methods}

\subsection{Fish}

A total of 2400 O. niloticus fries (mean individual initial weight $4 \pm 1.0 \mathrm{~g}$ ) were obtained from Abbasa hatchery, they were divided into six equal groups, each consisting of four replicates (100 fry/replicate) in 6 separate earthen ponds, Fish in each replicate were reared in a hapa made of cotton mesh like a cage $(3 \times 2 \times 1 \mathrm{~m}$, each) that was fixed in an earthen pond (for each group, a total of 4 hapas were equally arranged in 4rows). The whole experiment was done at the experimental units of The World Fish centre, Abbasa, Sharkia, Egypt. The Fish were fed twice daily on a basal diet of $35 \%$ protein at $10 \%$ of body weight per day. The feed was placed in plastic trays fitted in the hapas (one per hapa). The water was partially renewed daily and monitored regularly; the water temperature was maintained at $25 \pm 1{ }^{\circ} \mathrm{C}$.

\subsection{Spirulina Platensis}

Pure dried S. platensis (Arthrospira platensis) tablets were obtained from Lake Heath Products Co., Ltd. Liyang City, Jiangsu Province, China. It was dark pure green in colour with smooth surface. The tablets were grounded to a powder form before usage.

\subsection{Rations}

A standard commercial ration containing crude protein, crude lipid, vitamins and minerals met the basic dietary requirements of Nile tilapia was prepared (Table 1). The ingredients were mixed mechanically by the horizontal mixer (Hobarts model D300-T, Troy, OH, USA). The pellets were then prepared using a pellet-machine (California Pellet Mill, Roskamp Huller Co.) with $0.5 \mathrm{~cm}$ diameter and pellets were left for $24 \mathrm{~h}$ for air-drying at room temperature $\left(28^{\circ} \mathrm{C}\right)$, broken into small pieces and sieved to obtain the appropriate size. The rations were transferred into plastic bags and stored in a refrigerator at $4^{\circ} \mathrm{C}$ until used. Six experimental rations were prepared. The first five groups were prepared by mixing separately a graded concentration of S. platensis $5,7.5,10,15$ and $20 \mathrm{~g}$ S. platensis $/ \mathrm{kg}$ diet. The last group was assigned as control ration which consisted of the standard commercial ration without any treatment. The required diet was prepared biweekly and stored in a refrigerator $\left(4^{\circ} \mathrm{C}\right)$ for daily use.

Table 1. Composition of the Oreochromis niloticus basal diet used throughout the experiment

\begin{tabular}{cccccc}
\hline \multirow{2}{*}{ Ingredients } & \multirow{2}{*}{ Diet (\%) } & \multicolumn{2}{c}{ Protein (\%) } & \multicolumn{2}{c}{ Metabolic energy (Joules) } \\
\cline { 3 - 5 } & & ingredients & Feed & Ingredients & feed \\
\hline Fish meal & 7.95 & 0.72 & 5.76 & 4000 & 32000 \\
Soybean meal & 52.8 & 0.48 & 25.39 & 2870 & 151823 \\
Ground corn & 29.1 & 0.10 & 3.17 & 1240 & 36084 \\
Wheat flour & 5.00 & 0.13 & 0.67 & 2700 & 13500 \\
Vegetable oil & 2.00 & 0.00 & 0.00 & 9100 & 18200 \\
Cod liver oil & 2.00 & 0.00 & 0.00 & 9100 & 18200 \\
Di calcium phosphate & 1.00 & 0.00 & 0.00 & 0.00 & 0000 \\
Mineral mix. & 0.07 & 0.00 & 0.00 & 0.00 & 0000 \\
Vitamin mix. & 0.05 & 0.00 & 0.00 & 0.00 & 0000 \\
Total & 100 & 0.00 & 34.99 & 0.00 & 269807 \\
\hline
\end{tabular}




\subsection{Pathogen}

Pseudomonas fluorescens was previously isolated from naturally infected $O$. niloticus and identified according to the standard bacteriological tests. The pathogen was cultured in Tryptic Soya broth (TSB) (Oxoid) for $24 \mathrm{~h}$ at $37^{\circ} \mathrm{C}$. The broth culture was centrifuged for $10 \mathrm{~min}$ at $3000 \mathrm{rpm}$. The supernatant was discarded and the pellets were re-suspended in phosphate buffered saline at pH 7.4 (PBS 7.4) and the optical density (OD) of the solution was adjusted to 0.5 at $456 \mathrm{~nm}$, which correspond to $1 \times 10^{8}$ cells $\mathrm{mL}^{-1}$. This bacterial suspension was serially diluted using standard dilution technique with PBS 7.4 and used for the challenge experiment.

\subsection{Experimental Design}

To evaluate the efficacy of SP on cultured $O$. niloticus; three month feeding study periods were conducted. The pre-acclimated fish were divided into 6 equal groups. Group 1 was fed on a basal diet (control) and the five groups were dietary supplemented with single graded concentration of dried SP 5, 7.5, 10, 15 and $20 \mathrm{~g} \mathrm{~kg}^{-1}$ diet fed, respectively. Groups were evaluated for growth performance expressed as survival, specific growth rate, and condition factor. Blood samples were collected after 1,2, and 3 months for hematological analysis and immunological investigations. At the end of each month, the mortalities as well as the relative level of protection were estimated post challenge infections using $P$. fluorescens.

\subsection{Growth Performance and Survival}

Fish of all replicates were weighed individually and their body weight gain was measured. Specific growth rate (SGR) and condition factor (CF) were calculated according to Goodwin et al. (1983). The survival percentage was recorded along the period of experiment.

$\mathrm{SGR}=\mathrm{Ln}[$ final mean body weight $(\mathrm{g})]-\mathrm{Ln}[$ initial mean body weight $(\mathrm{g})] \div$ time interval $($ days $) \times 100$

$$
\mathrm{CF}=\text { weight }(\mathrm{g}) \div[\text { length }(\mathrm{cm})]^{3}
$$

\section{Hematological and Immunological Analysis}

\subsection{Blood Sampling}

Twenty fish were randomly collected from each group and were anesthetized via immersing in water containing tricaine methane sulfonate (MS-222) neutralized by sodium bicarbonate. Whole blood $(0.5 \mathrm{ml})$ pooled samples were collected from the caudal vessels of each fish using syringes $(1 \mathrm{ml})$ and 27 -gauge needles rinsed with heparin (15 unit $/ \mathrm{m})$.

A further $0.5 \mathrm{ml}$ blood sample was centrifuged at $2000 \mathrm{rpm}$ for $5 \mathrm{~min}$ in order to separate the plasma. The latter was stored at $-20^{\circ} \mathrm{C}$.

\subsection{Hematocrit (HCT) Values}

Hematocrit capillary tubes were two-third filled with the whole blood and centrifuged in a hematocrit centrifuge for $5 \mathrm{~min}$ and the percentage of the packed cell-volume was determined by the hematocrit tube reader.

\subsection{Nitroblue Tetrazolium (NBT) Activity}

The production of oxygen radicals from phagocytes in the blood was measured using nitroblue tetrazolium (NBT) dye as described by Anderson and Siwicki (2005). Briefly, blood $(0.1 \mathrm{ml})$ was placed in microtiter plate wells, to which an equal amount of $0.2 \%$ NBT solution was added and incubated for $30 \mathrm{~min}$ at room temperature. A sample of NBT blood cell suspension $(0.05 \mathrm{ml})$ was added to a glass tube containing $1 \mathrm{ml} \mathrm{N}$,N-dimethyl formamide and centrifuged for $5 \mathrm{~min}$ at $3000 \mathrm{rpm}$. The supernatant fluid was measured in a spectrophotometer at $620 \mathrm{~nm}$ in $1 \mathrm{ml}$ cuvettes.

\subsection{Adherence/NBT Assays}

Nitroblue tetrazolium-glass adherent assays (NBT-glass adherent assay) were performed by placing single drops of blood $(0.1 \mathrm{ml})$ on 2 glass cover slips and incubating them for $30 \mathrm{~min}$ at room temperature. The cover slips were then gently washed with phosphate buffered saline (PBS). Drops $(0.1 \mathrm{ml})$ of $0.2 \%$ NBT were placed on microscope slides and covered by a cover slip, then incubated at room temperature for 30 min with the NBT solution. The activated neutrophils were then counted under electric light microscope $(\times 400)$.

\subsection{Lysozyme Activity}

The lysozyme activity was measured using the turbidity assay. Chicken egg lysozyme (Sigma) was used as a standard and $0.2 \mathrm{mg} / \mathrm{ml}$ lyophilized Micrococcus lysodeikticus in $0.04 \mathrm{M}$ sodium phosphate buffer ( $\mathrm{pH} 5.75$ ) was used as a substrate. Plasma (50 $\mu \mathrm{g})$ samples were added to $2 \mathrm{ml}$ of bacterial suspension and the reduction in the 
absorbance at $540 \mathrm{~nm}$ was determined after 0.5 and $4.5 \mathrm{~min}$ incubation at $22^{\circ} \mathrm{C}$. One unit of lysozyme activity was defined as a reduction in absorbance of $0.001 \mathrm{~min}^{-1}$.

\subsection{Challenge of Fish}

For the challenge experiments; The supplemented and the control groups were subjected to three challenge infections, post 1, 2 and 3 months feeding trials; for this purpose; a total of 72 fish from each treatment (18 from each replicates) were used for challenge test, these fish were divided into two groups (each 36). Each group was subdivided into 3 subgroups (replicates, each 12) each subgroup reared in glass aquaria $(50 \times 60 \times 70 \mathrm{~cm})$. The groups were injected intraperitoneally with $0.5 \mathrm{ml}$ of $4 \times 10^{8} P$. fluorescens. The challenged fish, from each aquarium, were observed for 10 days in order to record the daily mortality.

The relative level of protection (RLP) among the challenged fish was determined

RLP $\%=1-$ (percent of mortality in treated groups/ percent of mortality in control group) $\times 100$.

\section{Statistical Analysis}

The mean and standard error were calculated for each variable. The data were analyzed by analysis of variance (ANOVA) to identify the significantly different groups at $(\mathrm{P}<0.05)$ by one way ANOVA with post hoc LSD multiple comparison test using SPSS software statistical program (SPSS for windows ver.15.00, USA).

\section{Results}

\subsection{Growth Performance}

Our study revealed that the growth performance expressed as body weight gain, specific growth rates, and condition factor, were significant $(\mathrm{p} \leq 0.05)$ in groups $3 \& 4$ in all periods versus the control group, with higher mean value level is in group 4 (Table 2).

Table 2. Growth performance and survival of experimental tilapia at end of the second month of feeding supplemented diet with Spirulina*,**

\begin{tabular}{|c|c|c|c|c|c|c|c|c|c|c|}
\hline \multirow{3}{*}{ Month } & \multirow{3}{*}{ Group } & \multirow{3}{*}{ Spirulina Dose } & \multicolumn{8}{|c|}{ Parameter } \\
\hline & & & \multicolumn{2}{|c|}{ Body Gain (g) } & \multicolumn{2}{|c|}{ Specific Growth Rate \% } & \multicolumn{2}{|c|}{ Condition Factor \% } & \multicolumn{2}{|c|}{ Survival \% } \\
\hline & & & Main & $\pm \mathrm{SE}$ & Main & $\pm \mathrm{SE}$ & Main & $\pm \mathrm{SE}$ & Main & $\pm \mathrm{SE}$ \\
\hline \multirow[t]{6}{*}{ First month } & Gp. 1 & Control (Zero Dose) & 8.48 & $0.68^{\mathrm{C}}$ & 1.88 & $0.10^{\mathrm{C}}$ & 1.67 & $0.02^{\mathrm{C}}$ & 87.67 & $1.45^{\mathrm{A}}$ \\
\hline & Gp. 2 & $5 \mathrm{~g} / \mathrm{kg}$ & 12.56 & $0.78^{\mathrm{B}}$ & 2.29 & $0.11^{\mathrm{BC}}$ & 1.82 & $0.02^{\mathrm{B}}$ & 88.67 & $2.40^{\mathrm{A}}$ \\
\hline & Gp. 3 & $7.5 \mathrm{~g} / \mathrm{kg}$ & 18.79 & $1.28^{\mathrm{A}}$ & 2.39 & $0.13^{\mathrm{AB}}$ & 1.82 & $0.02^{\mathrm{AB}}$ & 91.00 & $2.08^{\mathrm{A}}$ \\
\hline & Gp. 4 & $10 \mathrm{~g} / \mathrm{kg}$ & 20.33 & $0.99^{\mathrm{A}}$ & 2.63 & $0.09^{\mathrm{A}}$ & 1.88 & $0.02^{\mathrm{A}}$ & 91.67 & $2.03^{\mathrm{A}}$ \\
\hline & Gp. 5 & $15 \mathrm{~g} / \mathrm{kg}$ & 21.05 & $1.11^{\mathrm{A}}$ & 2.72 & $0.12^{\mathrm{A}}$ & 1.94 & $0.03^{\mathrm{A}}$ & 92.99 & $3.04^{\mathrm{A}}$ \\
\hline & Gp. 6 & $20 \mathrm{~g} / \mathrm{kg}$ & 21.95 & $0.95^{\mathrm{A}}$ & 2.84 & $0.08^{\mathrm{A}}$ & 1.97 & $0.02^{\mathrm{A}}$ & 94.00 & $3.33^{\mathrm{A}}$ \\
\hline \multirow[t]{6}{*}{ Second month } & Gp .1 & Control (Zero Dose) & 19.04 & $1.24^{\mathrm{C}}$ & 1.51 & $0.06^{\mathrm{C}}$ & 1.82 & $0.02^{\mathrm{C}}$ & 81.67 & $1.67^{\mathrm{B}}$ \\
\hline & Gp. 2 & $5 \mathrm{~g} / \mathrm{kg}$ & 19.50 & $1.39^{\mathrm{B}}$ & 1.88 & $0.06^{\mathrm{B}}$ & 1.94 & $0.02^{\mathrm{B}}$ & 83.00 & $1.53^{\mathrm{AB}}$ \\
\hline & Gp. 3 & $7.5 \mathrm{~g} / \mathrm{kg}$ & 31.10 & $2.00^{\mathrm{B}}$ & 2.04 & $0.07^{\mathrm{B}}$ & 1.99 & $0.02^{\mathrm{B}}$ & 85.67 & $1.20^{\mathrm{AB}}$ \\
\hline & Gp. 4 & $10 \mathrm{~g} / \mathrm{kg}$ & 37.39 & $2.16^{\mathrm{A}}$ & 2.27 & $0.07^{\mathrm{A}}$ & 2.21 & $0.03^{\mathrm{A}}$ & 87.67 & $1.45^{\mathrm{A}}$ \\
\hline & Gp. 5 & $15 \mathrm{~g} / \mathrm{kg}$ & 39.61 & $2.11^{\mathrm{A}}$ & 2.40 & $0.06^{\mathrm{A}}$ & 2.24 & $0.04^{\mathrm{A}}$ & 91.00 & $2.04^{\mathrm{A}}$ \\
\hline & Gp. 6 & $20 \mathrm{~g} / \mathrm{kg}$ & 42.33 & $1.99^{\mathrm{A}}$ & 2.57 & $0.08^{\mathrm{A}}$ & 2.29 & $0.02^{\mathrm{A}}$ & 92.20 & $1.98^{\mathrm{A}}$ \\
\hline \multirow[t]{6}{*}{ Third month } & Gp. 1 & Control (Zero Dose) & 35.33 & $2.29^{\mathrm{C}}$ & 1.46 & $0.05^{\mathrm{C}}$ & 1.79 & $0.02^{\mathrm{B}}$ & 79.00 & $2.51^{\mathrm{B}}$ \\
\hline & Gp. 2 & $5 \mathrm{~g} / \mathrm{kg}$ & 43.33 & $2.89^{\mathrm{Bc}}$ & 1.60 & $0.06^{\mathrm{Bc}}$ & 1.84 & $0.03^{\mathrm{B}}$ & $81.33^{\mathrm{B}}$ & $1.33^{\mathrm{A}}$ \\
\hline & Gp. 3 & $7.5 \mathrm{~g} / \mathrm{kg}$ & 51.75 & $4.12^{\mathrm{AB}}$ & 1.74 & $0.06^{\mathrm{AB}}$ & 2.02 & $0.03^{\mathrm{A}}$ & $83.67^{\mathrm{B}}$ & $0.88^{\mathrm{A}}$ \\
\hline & Gp. 4 & $10 \mathrm{~g} / \mathrm{kg}$ & 57.68 & $4.31^{\mathrm{A}}$ & 1.83 & $0.07^{\mathrm{A}}$ & 2.10 & $0.03^{\mathrm{A}}$ & 85.67 & $1.20^{\mathrm{A}}$ \\
\hline & Gp. 5 & $15 \mathrm{~g} / \mathrm{kg}$ & 59.90 & $5.11^{\mathrm{A}}$ & 1.85 & $0.06^{\mathrm{A}}$ & 2.20 & $0.03^{\mathrm{A}}$ & 88.45 & $1.11^{\mathrm{A}}$ \\
\hline & Gp. 6 & $20 \mathrm{~g} / \mathrm{kg}$ & 62.34 & $3.88^{\mathrm{A}}$ & 1.93 & $0.08^{\mathrm{A}}$ & 2.29 & $0.05^{\mathrm{A}}$ & 89.10 & $0.98^{\mathrm{A}}$ \\
\hline
\end{tabular}




\subsection{The Survival Rate}

During the feeding experiment, the survival \% expressed as mean \pm SE showed significant increases in group 4 at 2 month of experiment and in all S. platensis supplemented groups vs. the control group after the third month of experiment (Table 2).

\subsection{Hematological and Immunological Analysis}

A significant $(\mathrm{p} \leq 0.05)$ increase of hematocrit $(\mathrm{HCT})$ and nitroblue tetrazolium (NBT) were observed in all (with the exception of group 2 in case of NBT at 1st and 2nd month) S. platensis supplemented groups vs. the control group at all experimental period. On the other hand, Neutrophil Adherence values showed significant (p $\leq 0.05$ ) increase in all S. platensis supplemented groups vs. the control group (Table 3). The increase in the lysozyme activity was significant in all fish groups given basal diet supplemented with $S$. platensis at the 2nd and 3rd month (Table 2).

Table 3. Some hematological and immunological parameters of experimental tilapia at end of the first month of feeding supplemented diet with Spirulina*,**

\begin{tabular}{|c|c|c|c|c|c|c|c|c|c|c|}
\hline \multirow{3}{*}{ Month } & \multirow{3}{*}{ Group } & \multirow{3}{*}{ Spirulina Dose } & \multicolumn{8}{|c|}{ Parameter } \\
\hline & & & \multicolumn{2}{|c|}{ HCT } & \multicolumn{2}{|c|}{ NBT } & \multicolumn{2}{|c|}{$\begin{array}{l}\text { Nutrophyl } \\
\text { Adherence }\end{array}$} & \multicolumn{2}{|c|}{ Lysozyme activity } \\
\hline & & & Main & $\pm \mathrm{SE}$ & Main & $\pm \mathrm{SE}$ & Main & $\pm \mathrm{SE}$ & Main & $\pm \mathrm{SE}$ \\
\hline \multirow[t]{6}{*}{ First month } & Gp. 1 & Control (Zero Dose) & 27.25 & $1.24^{\mathrm{B}}$ & 0.23 & $0.02^{\mathrm{B}}$ & 9.00 & $1.61^{\mathrm{C}}$ & 8.59 & $1.39^{\mathrm{C}}$ \\
\hline & Gp. 2 & $5 \mathrm{~g} / \mathrm{kg}$ & 30.36 & $1.89^{\mathrm{A}}$ & 0.29 & $0.02^{\mathrm{AB}}$ & 10.30 & $1.59^{\mathrm{B}}$ & 9.89 & $1.40^{\mathrm{BC}}$ \\
\hline & Gp. 3 & $7.5 \mathrm{~g} / \mathrm{kg}$ & 31.40 & $1.00^{\mathrm{A}}$ & 0.33 & $0.03^{\mathrm{A}}$ & 10.99 & $1.58^{\mathrm{A}}$ & 11.25 & $1.61^{\mathrm{AB}}$ \\
\hline & Gp. 4 & $10 \mathrm{~g} / \mathrm{kg}$ & 32.95 & $1.10^{\mathrm{A}}$ & 0.38 & $0.05^{\mathrm{A}}$ & 11.80 & $1.59^{\mathrm{A}}$ & 11.65 & $1.71^{\mathrm{A}}$ \\
\hline & Gp. 5 & $15 \mathrm{~g} / \mathrm{kg}$ & 33.00 & $1.3^{\mathrm{A}}$ & 0.39 & $0.04^{\mathrm{A}}$ & 12.00 & $1.55^{\mathrm{A}}$ & 11.78 & $1.65^{\mathrm{A}}$ \\
\hline & Gp. 6 & $20 \mathrm{~g} / \mathrm{kg}$ & 33.10 & $1.1^{\mathrm{A}}$ & 0.41 & $0.03^{\mathrm{A}}$ & 12.20 & $1.48^{\mathrm{A}}$ & 11.90 & $1.72^{\mathrm{A}}$ \\
\hline \multirow[t]{6}{*}{ Second month } & Gp .1 & Control (Zero Dose) & 28.42 & $1.58^{\mathrm{B}}$ & 0.27 & $0.02^{\mathrm{C}}$ & 9.56 & $1.37^{\mathrm{B}}$ & 8.97 & $1.39^{\mathrm{C}}$ \\
\hline & Gp. 2 & $5 \mathrm{~g} / \mathrm{kg}$ & 31.38 & $1.02^{\mathrm{A}}$ & 0.34 & $0.03^{\mathrm{A}}$ & 11.30 & $1.52^{\mathrm{A}}$ & 10.26 & $1.45^{\mathrm{B}}$ \\
\hline & Gp. 3 & $7.5 \mathrm{~g} / \mathrm{kg}$ & 31.90 & $1.23^{\mathrm{A}}$ & 0.40 & $0.03^{\mathrm{AB}}$ & 11.41 & $1.41^{\mathrm{A}}$ & 11.80 & $1.44^{\mathrm{A}}$ \\
\hline & Gp. 4 & $10 \mathrm{~g} / \mathrm{kg}$ & 33.20 & $1.00^{\mathrm{A}}$ & 0.49 & $0.02^{\mathrm{A}}$ & 12.21 & $1.26^{\mathrm{A}}$ & 12.20 & $1.33^{\mathrm{A}}$ \\
\hline & Gp. 5 & $15 \mathrm{~g} / \mathrm{kg}$ & 33.50 & $1.44^{\mathrm{A}}$ & 0.51 & $0.04^{\mathrm{A}}$ & 12.54 & $1.37^{\mathrm{A}}$ & 12.58 & $1.44^{\mathrm{A}}$ \\
\hline & Gp. 6 & $20 \mathrm{~g} / \mathrm{kg}$ & 33.75 & $1.32^{\mathrm{A}}$ & 0.52 & $0.03^{\mathrm{A}}$ & 12.65 & $1.44^{\mathrm{A}}$ & 12.67 & $1.24^{\mathrm{A}}$ \\
\hline \multirow[t]{6}{*}{ Third month } & Gp. 1 & Control (Zero Dose) & 28.80 & $1.65^{\mathrm{B}}$ & 0.29 & $0.02^{\mathrm{B}}$ & 9.80 & $1.29^{\mathrm{B}}$ & 9.00 & $1.33^{\mathrm{C}}$ \\
\hline & Gp. 2 & $5 \mathrm{~g} / \mathrm{kg}$ & 33.30 & $1.49^{\mathrm{A}}$ & 0.35 & $0.01^{\mathrm{AB}}$ & 10.40 & $1.31^{\mathrm{B}}$ & 10.10 & $1.31^{\mathrm{B}}$ \\
\hline & Gp. 3 & $7.5 \mathrm{~g} / \mathrm{kg}$ & 33.40 & $1.52^{\mathrm{A}}$ & 0.36 & $0.02^{\mathrm{A}}$ & 11.50 & $1.23^{\mathrm{A}}$ & 10.40 & $1.27^{\mathrm{B}}$ \\
\hline & Gp. 4 & $10 \mathrm{~g} / \mathrm{kg}$ & 33.80 & $1.47^{\mathrm{A}}$ & 0.38 & $0.03^{\mathrm{A}}$ & 11.70 & $1.26^{\mathrm{A}}$ & 11.90 & $1.43^{\mathrm{A}}$ \\
\hline & Gp. 5 & $15 \mathrm{~g} / \mathrm{kg}$ & 34.10 & $1.48^{\mathrm{A}}$ & 0.39 & $0.02^{\mathrm{A}}$ & 11.80 & $1.32^{\mathrm{A}}$ & 12.00 & $1.33^{\mathrm{A}}$ \\
\hline & Gp. 6 & $20 \mathrm{~g} / \mathrm{kg}$ & 34.44 & $1.51^{\mathrm{A}}$ & 0.35 & $0.04^{\mathrm{A}}$ & 12.00 & $1.25^{\mathrm{A}}$ & 12.22 & $1.28^{\mathrm{A}}$ \\
\hline
\end{tabular}

\subsection{The Mortality Rate}

Following the challenge infection using $P$. fluorescens the mortality rate was significantly lower in all S. platensis supplemented groups vs. the control throughout the experimental period.

\subsection{The Relative Level of Protection (RLP)}

The results recorded in (Table 4) evoked significant protection in all S. platensis supplemented groups vs. the control.

It worth mentioned that the mean value level is in-group 4 (group received $10 \mathrm{~g} / \mathrm{kg}$ ) is higher in all the tested parameters with significant difference. 
Table 4. Mortality and relative level of protection of experimental tilapia at end of the first, second and third months of feeding supplemented diet with Spirulina after challenged with Pseudomonas florescence, **

\begin{tabular}{|c|c|c|c|c|c|}
\hline \multirow{3}{*}{ Month } & \multirow{3}{*}{ Group } & \multirow{3}{*}{ Spirulina Dose } & \multicolumn{3}{|c|}{ Pseudomonas florescence } \\
\hline & & & \multicolumn{2}{|c|}{ Mortality \% } & \multirow{2}{*}{ RLP \% } \\
\hline & & & Main & $\pm \mathrm{SE}$ & \\
\hline \multirow[t]{6}{*}{ First month } & Gp.1 & Control (Zero Dose) & 65.00 & $5.00^{\mathrm{C}}$ & 0.00 \\
\hline & Gp.2 & $5 \mathrm{~g} / \mathrm{kg}$ & 60.00 & $2.89^{\mathrm{B}}$ & 8.3 \\
\hline & Gp.3 & $7.5 \mathrm{~g} / \mathrm{kg}$ & 58.33 & $1.67^{\mathrm{B}}$ & 10.26 \\
\hline & Gp. 4 & $10 \mathrm{~g} / \mathrm{kg}$ & 54.67 & $1.67^{\mathrm{AA}}$ & 15.8 \\
\hline & Gp. 5 & $15 \mathrm{~g} / \mathrm{kg}$ & 52.20 & $1.54^{\mathrm{A}}$ & 19.69 \\
\hline & Gp. 6 & $20 \mathrm{~g} / \mathrm{kg}$ & 50.12 & $2.45^{\mathrm{A}}$ & 22.89 \\
\hline \multirow[t]{6}{*}{ Second month } & Gp.1 & Control (Zero Dose) & 66.67 & $1.67^{\mathrm{C}}$ & 0.00 \\
\hline & Gp. 2 & $5 \mathrm{~g} / \mathrm{kg}$ & 56.67 & $1.67^{\mathrm{B}}$ & 15.00 \\
\hline & Gp. 3 & $7.5 \mathrm{~g} / \mathrm{kg}$ & 53.33 & $1.67^{\mathrm{B}}$ & 20.01 \\
\hline & Gp. 4 & $10 \mathrm{~g} / \mathrm{kg}$ & 51.67 & $1.67^{\mathrm{A}}$ & 22.50 \\
\hline & Gp. 5 & $15 \mathrm{~g} / \mathrm{kg}$ & 49.45 & $1.54^{\mathrm{A}}$ & 25.83 \\
\hline & Gp. 6 & $20 \mathrm{~g} / \mathrm{kg}$ & 48.00 & $1.76^{\mathrm{A}}$ & 28.00 \\
\hline \multirow[t]{6}{*}{ Third month } & Gp.1 & Control (Zero Dose) & 63.33 & $3.33^{\mathrm{C}}$ & 0.00 \\
\hline & Gp. 2 & $5 \mathrm{~g} / \mathrm{kg}$ & 51.37 & $1.67^{\mathrm{B}}$ & 18.60 \\
\hline & Gp. 3 & $7.5 \mathrm{~g} / \mathrm{kg}$ & 48.33 & $1.67^{\mathrm{B}}$ & 23.70 \\
\hline & Gp. 4 & $10 \mathrm{~g} / \mathrm{kg}$ & 41.67 & $1.33^{\mathrm{A}}$ & 34.20 \\
\hline & Gp. 5 & $15 \mathrm{~g} / \mathrm{kg}$ & 40.00 & $1.42^{\mathrm{A}}$ & 36.84 \\
\hline & Gp. 6 & $20 \mathrm{~g} / \mathrm{kg}$ & 38.00 & $1.54^{\mathrm{A}}$ & 40.00 \\
\hline
\end{tabular}

* In all tables: Gp.1: First group, Gp.2: Second group, Gp.3: Third group, Gp.4: Fourth group.

**Means with the same letter in the same column are not significantly different.

\section{Discussion}

The primary objective in fish nutrition is to provide a nutritionally balanced mixture of ingredients to support the fish vital functions in an acceptable cost (NRC, 1993). S. platensis was reported to improve feed efficiency, carcass quality, and physiological response to stress in several species of fish (Takeuchi et al., 2002). None of the previous studies recommended an optimum concentration of dietary S. platensis b] ased on graded level study.

Spirulina appeared to be a useful tool to include in the arsenal of disease control and prevention. However, it must not replace good management techniques. The strength of spirulina appears to lie in its ability to improve growth, survival and non-specific immune function against fish pathogens as well as its chemo-protective efficiency. The algae may significantly aid the aquaculture industry.

In the current study we expanded the S. platensis dietary concentration to be $0.05,7.5,10,15$ and $20 \mathrm{~g} / \mathrm{kg}$ in order to assess the optimum dietary concentration for $O$. niloticus using pure whole $S$. platensis in powder form.

Specific growth rate (SGR) and condition factor (CF) are the measuring tools reflecting the fish health status under natural and experimental conditions. In the current study pure dried S. platensis found to be of potential effects on growth at an optimum concentration of 7.5 and $10 \mathrm{~g} / \mathrm{kg}$. It worth mentioned that the mean value level in the group received $10 \mathrm{~g} / \mathrm{kg}$ is higher in all the tested parameters with significant difference; these results cleared that the optimum dietary level of S. platensis for O. niloticus is $10 \mathrm{~g} / \mathrm{kg}$ for 2 months to enhance growth performance. Duncan and Klesius (1996) reported that Spirulina alga was a good source of protein for animal feed, being containing high amounts of vitamins and minerals, in addition, Nakono et al. (2003) recorded that the lack of cellulose from the cellular structure of Spirulina render it easily digestible, thus, increase fish appetite, improve 
feed intake and nutrient digestibility and in turn enhance the health of fish, increasing the ability to fight off infections through the reduction of stress levels. The results in the current study are in accordance with Watanabe et al. (1990) and Takeuchi et al. (2002) who found that feed supplemented with S. platensis powder improved the feed conversion ratio and growth rates in striped jack, Pseudocaranx dentex. Lu et al. (2002) demonstrated that raw S. platensis can be an effective uni-feed for larval tilapia at a feeding rate of $30 \%$ (on a dry basis) of body weight. Abdel-Tawwab and Ahmed (2009) recorded that the growth and feed utilization of O. niloticus were obtained at $5.0 \mathrm{~g}$ fresh culture of S. platensis $/ \mathrm{kg}$ diet. On the contrary, Ungsethaphand et al. (2010) recorded that the final weight gain, specific growth rate, feed conversion ratio of hybrid red tilapia were not affected by $S$. platensis supplementation. These variations might be attributed to the difference in the $S$. platensis concentration to exert the intended effects, the form of S. platensis, raw or dried S. platensis or even its products, fish species and size in addition to the rearing conditions.

The high survival rate results in the current study are consistent with that recorded by Dernekbasi et al. (1993) who observed good survival rates in all Guppies treated with S. platensis using $40 \%$ S. platensis supplementation. However, the previous study did not mention the form of $S$. platensis used; in addition, the difference in the spirulina concentration could be related to the difference in the feeding habits of the fish species. In contrary to our results Abdel-Tawwab and Ahmed (2009), and Ungsethaphand et al. (2010) found no significant changes in the survival rates of fish dietary supplemented with S. platensis at different concentrations.

Adherence/NBT (nitroblue tetrazolium) and respiratory burst process assay spotlights on the non-specific immune response and the antibacterial mechanisms of the tested substances. The results of the current feeding trial showed a significant increase of nitroblue tetrazolium (NBT) and Neutrophil Adherence values in most of the $S$. platensis supplemented groups. The current results agree with those of Duncan and Klesius (1996) who reported enhancement of the peritoneal phagocytes from channel catfish, I. punctatus fed S. platensis, Spirulina algae contain carotenoids, which specifically improving fish health and increasing the ability to fight off infections through the reduction of stress levels. In addition, Watanuki et al. (1990) reported that S. platensis activated the functions of leucocytes, such as phagocytosis and production of superoxide, and cytokines production in common carp, Cyprinus carpio.

The present study found that fish fed with $10 \%$ spirulina exhibited significant haematocrit values. The increase in the immunity stimulating capacity (measure by a lysozyme activity assay) was significant in all fish groups given basal diet supplemented with S. platensis at the $2^{\text {nd }}$ and $3^{\text {rd }}$ month.

Lysozyme is found in a wide range of vertebrates including fish and is one of the defensive factors against invasion by microorganisms. The increase in the immunity stimulating capacity could be due to the presence of C-phycocyanin in the Spirulina alga, which can help build the immunity capacity (Vonshak, 1997). Results were in accordance with Tayag et al. (2010) who concluded that the white shrimp L. vannamei that received the hot-water extract of $S$. platensis had enhanced innate immunity as lysozyme and increased resistance against $V$. alginolyticus infection.

The challenge infection revealed a significantly lower mortality percentage in the group received $10 \mathrm{~g} / \mathrm{kg} S$. platensis in diet for the 1, 2 and 3 months feeding trial and significantly high relative level of protection (RLP) after challenge infection using $P$. fluorescens. The disease challenge is an in vitro technique provides an opportunity to determine the performance and immunity of the fish species ebon exposure to xenobiotic (bacteria) on their natural habitats (AraKoosh et al., 2009). The results were in accordance with Watanuki et al. (2006) who recorded an increased resistance of S. platensis treated carp ebon artificial challenge with A. hydrophila than the control group. Abdel-Tawwab and Ahmad (2009) found that SP has a useful impact on fish as immuno-stimulants, they recorded that tilapia fed 5-10 g fresh $S$. platensis $/ \mathrm{kg}$ diet increased its resistance against $A$. hydrophyla.

Finally, from the present investigation, it was concluded that optimized the dietary levels of dried Spirulina in $O$. niloticus, was useful to decrease costs of the products used and negate losses that could be encountered with improper supplementation levels. It was proved that the optimum concentration of dried S. platensis in the $O$. niloticus practical diet is $10 \mathrm{~g} / \mathrm{kg}$ for 2 months, to positively improving health conditions, enhanced the non-specific immunity of Oreochromis niloticus, as well as its resistance to challenge by $P$. fluorescens infections. It is recommended to supplement Spirulina in the diet of Nile tilapia especially those grow in farms under immunosuppressive/stressful conditions. Additional researches are needed to study additional desired effects of the blue green algae in cultured fish. 


\section{References}

Abdel-Tawwab, M., \& Ahmad, H. M. (2009). Live Spirulina platensis (Arthrospira platensis) as a growth and immunity promoter for Nile tilapia, Oreochromis niloticus (L.), challenged with pathogenic Aeromonas hydrophila. Aquaculture Res., 40, 1037-1046. http://dx.doi.org/10.1111/j.1365-2109.2009.02195.x

Anderson, D. P., \& Siwicki, A. K. (1995). Basic hematology and serology for fish health programs. In M. Shariff, J. R. Auther, \& R. P. Subasinghe (Eds.), Diseases in Asian Aquaculture II (pp. 185-202). Fish Health Section, Asian Fisheries Society, Manila.

AraKoosh, M. R., Boylen, D., Stafford, C. L., Johnson, L. L., \& Collier, T. K. (2005). Use of disease challenge assay to assess immunotoxicity of xenobiotics in fish (pp. 19-22). National Oceanic and Atmospheric Administration, CRC Press.

Chow, C. Y., \& Woo, N. Y. S. (1990). Bioenergetics studies on an omnivorous fish Oreochromis mossambicus: Evaluation of the utilization of Spirulina platensis algae in feed. In R, Hirano, \& I. Hanyu (Eds.), Proceeding of the 2nd Asian Fisheries Forum (pp. 291-294). The Asian Fisheries Society; Manila.

Dernekbas, I. S., Unal, H., Karayucel, I., \& Aral, O. (2010). Effect of dietary supplementation of different rates of Spirulina platensis (S. platensis) on growth and feed conversion in Guppy (Poecilia reticulate Peters, 1860). J. Anim. Vet. Adv., 9, 1395-1399.

Duncan, P. L., \& Klesius, P. H. (1996). Effects of feeding Spirulina platensis on specific and non-specific immune responses of channel catfish. J. Aquat. Animal Health, 8, 308-313. http://dx.doi.org/10.1577/1548-8667(1996)008<0308:EOFSOS $>2.3 . C O ; 2$

Gatlin, D. M., Li, P., Wang, X., Burr, G. S., Castille, F., \& Lawrence, A. L.(2006). Potential application of prebiotics in aquaculture, 8th International simposium on aquaculture nutrition (pp. 371-376).

Goodwin, T. W., \& Mercer EI. (1983). Fructosans. In T. W. Goodwin, E. I. Mercer (Eds.), Introduction to plant biochemistry (pp. 261-4). Oxford: Pergamon Press.

Grawish, M. E. (2008). Effects of Spirulina platensis extract on Syrian hamster cheek pouch mucosa painted with 7,12-dimethylbenz[a] anthracene. Oral Oncol, $44,4662$. http://dx.doi.org/10.1016/j.oraloncology.2007.11.014

Ibrahem, M. D., Fathi, M., Mesalhy, S., \& Abd El-Aty, A. M. (2010). Effect of dietary supplementation of inulin and vitamin $\mathrm{C}$ on the growth, hematology, innate immunity, and resistance of Nile tilapia (Oreochromis niloticus). Fish Shellfish Immunol, 29, 241-6. http://dx.doi.org/10.1016/j.fsi.2010.03.004

Kaizu, A., Fagutao, F. F., Kondo, H., Aok, I. T., \& Hirono, I. (2011). Functional Analysis of a C-Type Lysozyme in Penaeid Shrimp. Biol Chem.

Kaji, T., Fujiwara, Y., \& Inomata, Y. (2002). Repair of wounded monolayers of cultured bovine aortic endothelial cells is inhibited by calcium spirulan, a novel sulfated polysaccharide isolated from Spirulina platensis. Life Sci., 70, 1841-8. http://dx.doi.org/10.1016/S0024-3205(01)01555-7

Lu, J., Yoshizaki, G., Sakai, K., \& Takeuchi, T. (2002). Acceptability of raw Spirulina platensis by larval tilapia Oreochromis niloticus. Fish Sci., 68, 51-58. http://dx.doi.org/10.1046/j.1444-2906.2002.00388.x

Nakono, T., Yamaguchi, T., Sato, M., \& Iwama, G. K. (2003). Biological Effects of Carotenoids in Fish (pp. 1-15). International Seminar "Effective Utilization of Marine Food Resource", Songkhla, Thailand, 18 December 2003.

NRC Nutrient requirements of fish. (1993). Washington DC: National Academy Press.

Ozdemir, G., Karabay, N. U., Dalay, M., \& Pazarbasi, B. (2004). Antibacterial activity of volatile component and various extracts of Spirulina Platensis. Phytother-Res., 18, 754-757. http://dx.doi.org/10.1002/ptr.1541

Romay, C., Armesto, J., \& Remirez, D. (1998). Antioxidant and anti-inflammatory properties of C-phycocyanin from blue-green algae. Inflamm Res., 47, 36-41. http://dx.doi.org/10.1007/s000110050256

Takeuchi, T. J., Lu, G., Yoshizaki, Y., \& Satoh, S. (2002). Effect on the growth and body composition of juvenile tilapia Oreochromis niloticus fed raw Spirulina platensis. Fish Sci., 68, 34-40. http://dx.doi.org/10.1046/j.1444-2906.2002.00386.x

Tayag, C. M., Lin, Y. C., Li, C. C., Liou, C. H., \& Chen, J. C. (2010). Administration of the hot-water extract of Spirulina platensis enhanced the immune response of white shrimp Litopenaeus vannamei and its resistance 
against Vibrio alginolyticus. Fish Shellfish Immunol, 28(5-6), 764-73. http://dx.doi.org/10.1016/j.fsi.2010.01.023

Ungsethaphand, T., Peerapornpisal, Y., Whangchai, N., \& Sardsud, U. (2010). Effect of feeding Spirulina platensis on growth and carcass composition of hybrid red tilapia (Oreochromis mossambicus $\times O$. niloticus). Maejo Int. J. Sci. Technol., 4, 331-336.

Vonshak, A. (1997). Spirulina platensis (Arthospira): Physiology, Cell Biology and Biotechnology (p. 540). London: Taylor and Francis.

Watanabe, T., Liao, W., Takeuchi, Y. T., \& Yamamoto, H. (1990). Effect of dietary Spirulina platensis supplement on growth performance and flesh lipids of cultured striped jack. J. Tokyo Univ. Fish., 77, 231-239.

Watanuki, H., Ota, K., Malin, A. C., Tassakka, A. R., Kato, T., \& Sakai, M. (2006). Immunostimulant effects of dietary Spirulina platensis on carp, Cyprinus carpio. Aquaculture, 258, 157-163. http://dx.doi.org/10.1016/j.aquaculture.2006.05.003

Yousefian, M., \& Amiri, M. S. (2009). A. review of the use of prebiotic in aquaculture for fish and shrimp. Afr. J. Biotechnol, 8, 7313-7318. 